\title{
Reclaiming a future that has not yet been: The Faure report, UNESCO's humanism and the need for the emancipation of education
}

\author{
Gert Biesta $^{1,2}$ (D \\ Published online: 12 October 2021 \\ (C) The Author(s) 2021
}

\begin{abstract}
Fifty years after UNESCO's publication of Learning to be: The world of education today and tomorrow, the author of this article provides an assessment of this seminal report, commonly known as "the Faure report". He characterises the educational vision of the report as humanistic and democratic and highlights its emphasis on the need for educational provision throughout the life-course. He demonstrates how the right to education has, over time, been transformed into a duty to learn, Moreover, this duty has been strongly tied to economic purposes, particularly the individual's duty to remain employable in a fast-changing labour market. Rather than suggesting that Edgar Faure and his International Commission on the Development of Education set a particular agenda for education that has, over time, been replaced by an altogether different agenda, the author suggests a reading of the report which understands it as making a case for a particular relationship between education and society, namely one in which the integrity of education itself is acknowledged and education is not reduced to a mere instrument for delivering particular agendas. Looking back at the report five decades later, he argues that it provides a strong argument for the emancipation of education itself, and that this argument is still needed in the world of today.
\end{abstract}

Keywords Faure report - UNESCO · humanism · technicism · emancipation · learning society $\cdot$ permanent education

\section{Résumé}

Se réapproprier un avenir encore lointain : Rapport Faure, humanisme de l'UNESCO et nécessité d'émanciper l'éducation - Cinquante ans après la publication de l'UNESCO Apprendre à être : le monde de l'éducation aujourd'hui et demain,

Gert Biesta

gert.biesta@ed.ac.uk

1 Centre for Public Education and Pedagogy, Maynooth University, Maynooth, Ireland

2 Moray House School of Education and Sport, University of Edinburgh, Edinburgh, UK 
l'auteur de l'article dresse un bilan de ce rapport fondateur, communément appelé Rapport Faure : il qualifie d'humaniste et de démocratique la vision éducative dans cet ouvrage et met l'accent sur la nécessité de prestations éducatives tout au long de la vie. Il démontre comment le droit à l'éducation s'est progressivement transformé en un devoir d'apprendre. Ce devoir est en outre aujourd'hui fortement associé à des objectifs économiques, en particulier le devoir individuel de maintenir son employabilité sur un marché du travail en constante mutation. Au lieu de suggérer qu'Edgar Faure et sa Commission internationale pour le développement de l'éducation ont établi un projet spécifique pour l'éducation qui, au fil du temps, a été remplacé par une conception totalement différente, l'auteur en propose une nouvelle lecture pour l'appréhender comme un plaidoyer en faveur d'une relation particulière entre éducation et société : l'éducation y est reconnue dans son intégrité et n'est pas réduite à un simple instrument pour réaliser des programmes spécifiques. Revenant sur ce texte après cinq décennies, l'auteur affirme qu'il fournit un argument de poids, toujours nécessaire dans le monde d'aujourd'hui, en faveur de l'émancipation de l'éducation.

\section{Introduction: A future that has not yet been?}

Learning to be: The world of education today and tomorrow (Faure et al. 1972) was published by the United Nations Educational, Scientific and Cultural Organization (UNESCO) in 1972. It is commonly known as the "Faure report", named after Edgar Faure, chairman of UNESCO's International Commission on the Development of Education. Reading the report almost 50 years after its publication is not only a remarkable experience in light of the depth and breadth of the educational vision put forward by its authors. It is even more remarkable in light of the trajectory that the discourse on education through the life-course ${ }^{1}$ has taken since its publication.

The explicitly humanistic and democratic approach to education that permeates Learning to be is hardly recognisable in contemporary discussions, in which the right to permanent education (éducation permanente in French; see e.g. Jessup 1973) seems to have been replaced by the duty to continue to learn throughout one's life (for a discussion of this reversal, see Biesta 2006, 2012). The main purpose of this duty to learn - termed Bildungspflicht in German (Messerschmidt 2011, p. 18) - is for individuals to keep themselves employable in fast-changing labour markets. It seems safe to conclude, therefore, that tomorrow's "world of education" as envisaged by Faure and his co-authors in the early 1970s has not arrived - or, in a more optimistic reading, has not yet arrived.

While developments that have occurred since the publication of the report have played an important role in this shift of focus, the early signs were not entirely encouraging either. In her analysis of the reception of the report, Maren Elfert (2018, pp. 126-133) documents ciritics' dissatisfaction with what they saw as the

\footnotetext{
${ }^{1}$ I use the notion of "education through the life-course" in order to avoid using phrases such as "permanent education", "lifelong education" and "lifelong learning". This enables me to analyse the rhetorical force and significance of these particular terms.
} 
too general and too philosophical nature of the report, and its lack of suggestions for concrete action. She also quotes a rather strong statement from a representative of the Organisation for Economic Co-operation and Development (OECD), which seems to indicate that OECD's world of education (discussed in more detail later in this article) was already significantly different from the one the Faure report sought to bring into existence.

I do not think the school experience is a useful experience for life if it is designed to avoid subjecting the student to hierarchy, competition, outside measures of learning achievement of some sort, or frustration, or if it operates from beginning to end on the basis of the prescribed principles of democracy, unless it is assumed that the society which the student enters operates itself on the principles of philosophical anarchy (OECD 1972, p. 1, quoted in Elfert 2018, p. 128).

This quotation is indicative of what is both a fundamental and a foundational dilemma of education (for more on the latter, see Säfström 2019). The dilemma is whether education should be situated on the side of control or on the side of freedom, bearing in mind that education's relationship with freedom is not one of anarchy; rather, it is related to the question of democracy.

In this article I provide a reading of the Faure report in light of subsequent developments in the discourse, policy and practice of education, particularly education through the life-course. In my analysis I highlight the shift from a humanistic to an economic agenda for education, and the transformation of lifelong education as a right to lifelong learning as a duty. The main suggestion I make in this article is that these developments should not so much be understood in terms of different agendas for education, but rather signify an ongoing functionalisation and instrumentalisation of education. Instead of trying to reclaim the worthy humanistic ethos of Faure's report and UNESCO's ambitions more generally, I suggest that work towards what I will refer to as the "emancipation" of education itself may be a more meaningful way forward, that is, one in which there may still be a future for Faure's legacy.

\section{Faure's vision}

The first thing to bear in mind about Learning to be is that, as is the case with many of these kinds of commissioned reports, it is written by a committee and published on behalf of an organisation. This means that the text is at best a compromise between the views of the individual members of the committee (and in the case of the Faure report there was indeed disagreement within the committee; see Elfert 2018, p. 127). It also means that the voice of the committee is filtered by the political realities within which the sponsoring organisation is operating. This always raises the question about the difference between what might be desirable to say and what might be possible to say. It is not just that a report such as Learning to be seeks to speak to many different individuals and groups. It also seeks to speak on behalf of many, including those who, out of a range of different motivations, provide 
input to the committee, for example through the writing of background papers (see UNESCO 1975), or in conversations during the 23 country visits that were conducted as part of the preparation of the report (Faure et al. 1972, p. vii). Taking these circumstances into account helps to see that Learning to be is a delicate balancing act and a pragmatic intervention in a highly complex political field, and therefore a document that was unlikely to please everyone (see Elfert 2018, pp. 126-133).

Considering the Faure report from this angle therefore makes it even more remarkable how pronounced and articulate the vision put forward in Learning to be actually is, even if Edgar Faure, in his presentation letter to René Maheu, UNESCO's Director-General at the time, does highlight that the Commission was "entirely independent and free in formulating [their] ideas and therefore did not feel obliged to be neutral" (Faure et al. 1972, p. v). ${ }^{2}$ Faure's letter, included at the beginning of the published report (and followed by Maheu's reply letter), is also helpful because it summarises the "four basic assumptions" (ibid.) of the report in a very succinct way.

The first assumption, which provided "the justification for the task [the Commission] undertook" was that of

the existence of an international community which, amidst the variety of nations and cultures, of political options and degrees of development, is reflected in common aspirations, problems and trends, and its movement towards the same destiny (ibid., pp. v-vi).

The "corollary" of this, according to Faure, "is the fundamental solidarity of governments and of peoples, despite transitory differences and conflicts" (ibid., p. vi).

The second assumption is

the belief in democracy, conceived of as implying each man's right to realize his own potential and to share in the building of his own future (ibid.),

to which Faure adds that the "keystone" of democracy "is education - not only education that is accessible to all, but education whose aims and methods have been thought out afresh" (ibid.).

The third assumption is

that the aim of development is the complete fulfilment of man, in all the richness of his personality, the complexity of his forms of expression and his various commitments - as individual, member of a family and of a community, citizen and producer, invention of techniques and creative dreamer (ibid.).

Finally, the fourth assumption is

that only an over-all, lifelong education can produce the kind of complete man the need for whom is increasing with the continually more stringent constraints tearing the individual asunder (ibid.).

\footnotetext{
${ }^{2}$ Since the letter was written at the very end of the Commission's work on the report, it is quite likely that with this formulation Faure was already anticipating particular criticisms of the report and the work of the Commission.
} 
For Faure, this implies first and foremost that people "should no longer assiduously acquire knowledge once and for all, but learn how to build up a continually evolving body of knowledge all through life" - which, for Faure, all comes together in the idea of "learn[ing] to be" (ibid.).

One could argue that the four key terms here are "solidarity", "democracy", "fulfilment", and "lifelong education", but it is perhaps more appropriate to say that there are three central themes. This is because the idea of democracy is closely - and one could even say intrinsically - connected to the right of every human being (the language of the report is, of course, gender-insensitive) to realise their own potential. This reading of democracy is far less, if at all, about democracy as a political idea, and much more about the third assumption, that is, the idea of "the complete fulfilment of man" (which, by the way, is presented as "the aim of development" rather than the aim of education). The two assumptions (democracy and fulfilment) clearly position education on the side of freedom, not the side of control, but do so in an individualistic way.

This approach can definitely be characterised as humanistic. The report itself uses the phrase "scientific humanism" (see Faure et al. 1972, pp. 146-148) - Elfert (2018, p. 122) even calls Learning to be a "humanist manifesto" - which is in line with the overarching humanistic orientation of UNESCO (for a detailed discussion, see Elfert 2018, chapter 2). Yet the humanism of the Faure report is individualistic before it becomes collective and political, so to speak. ${ }^{3}$ The following passage is a clear expression of this order of priorities.

[I]t seems to us, that through the knowledge it provides of the environment in which it operates[,] education may help society to become aware of its problems and, provided that efforts are centred on training "complete men" who will consciously seek their individual and collective emancipation, it may greatly contribute to changing and humanizing societies (Faure et al. 1972, p. 56; emphasis in original).

All this does mean, and here the report takes a clear position, that "complete fulfilment" is a right for every human being, not just for the elites (see particularly Faure et al. 1972, chapter 5: "Education and society").

The second key message from the report, and perhaps the one that has become the most prominent legacy of the work of Faure and his colleagues (albeit with some limitations; see below) is the case against the sufficiency of "initial education" (Faure et al. 1972, p. 117). ${ }^{4}$ The report argues that there is a need for education to be available throughout one's life - which is better expressed in the French notion

\footnotetext{
3 This way of relating education and democracy is remarkably close to what I think John Dewey proposed, particularly in Democracy and Education (Dewey 1916) (see Biesta 2016). The main "issue" is that democracy appears in this constellation as an ideal environment and set of conditions for the optimal development of individuals, rather than as a political "set-up" which has a value in itself and may, precisely for that reason, limit the opportunities for individuals to develop, grow and fulfil themselves (on the latter point, see also Biesta 2014).

4 The term initial education refers to "the formal education of individuals before their first entrance to the labour market, i.e. when they will normally be in full-time education" (UIS 2012, p. 11).
} 
of éducation permanente [permanent education] than in the English term "lifelong education" - and that individuals therefore have an established right to education throughout their lives. This is captured in the argument for the development of a "learning society", which is the main theme of part three of the report (see Faure et al. 1972, particularly chapters 7 and 8). ${ }^{5}$

The third key theme of the report is the idea of solidarity. While the report is sensitive to the "variety of nations and cultures, of political options and degrees of development" (Faure et al. 1972, p. vi), it highlights the "movement towards one and the same destiny" (ibid.) and argues that despite differences and conflicts, which are seen as "transitory" (ibid.), all this amounts to "the fundamental solidarity of governments and of peoples" (ibid.). Philosophers might see this as a case of the naturalistic fallacy, where a factual statement is turned into a normative claim - from "is" to "ought". Yet perhaps the normativity already begins with the suggestion that humanity has a "common destiny". One could say that in the final chapter of the report, called "Roads to solidarity", the text becomes remarkably practical and in this regard takes the idea of solidarity amongst the nations, and the practical implications of this, entirely seriously.

\section{From "learning to be" to "learning to be productive and employable"}

As mentioned earlier, perhaps the most important legacy of the Faure report lies in its case for lifelong education (éducation permanente in French) and the development of a learning society (cité éducative in French). These ideas were not entirely new - they figured prominently in the work of Basil Yeaxlee in Britain and Eduard Lindeman in the United States, for example (see Lindeman 1926; Yeaxlee 1929) - but Learning to be gave these ideas new momentum, ${ }^{6}$ not least by connecting them explicitly to democracy, to the right to "fulfilment" and to global solidarity.

\section{Recurrent education - OECD's strategic stance in the early 1970s}

At about the same time as the publication of the Faure report, OECD's Centre for Educational Research and Innovation (CERI) contributed to the debate about the future of education along similar lines with the publication of Recurrent Education: A Strategy for Lifelong Learning (Kallen and Bengtsson 1973). This document

\footnotetext{
5 The report was originally drafted in French, which raises interesting issues about the translation of key concepts. In the French original, the term that became "learning society" in English was actually "cité educative", which, as Elfert (2018. p. 114) clarifies, has echoes of the Greek idea of the "polis" rather than the Anglo-Saxon idea of "society", and also, I wish to add, highlights education rather than learning. There were similar issues, and problems, with regard to the translation of the French words "homme" and "personne" (see Elfert 2018, p. 124), where the English word "man" seems to be a rather poor and also too gender-specific translation.

6 Another influential publication from this period is Swedish educationist Torsten Husén's book The Learning Society (Husén 1974), which he followed up in 1986 with The Learning Society Reconsidered (Husén 1986).
} 
focused predominantly on a number of structural problems in the educational provision for young people and adults. Against the idea that such problems could be effectively addressed by the expansion of "youth education", the authors made a case for "lifelong access to education" (ibid., p. 12; emphasis added) in the form of "recurrent education", understood as a form of educational provision based on "the principles of alternation between education and other activities" (ibid.).

While the document veered towards a "realistic" rather than an "optimistic" view about the potential of education to effect societal change (ibid., p. 31), it nonetheless displayed an awareness of the tension between "societal and educational objectives, and consequently between societal and educational change" (ibid.). Moreover, it took "the fundamental right of the individual to decide his own future" as the guiding principle of recurrent education (ibid., p. 32), and it explicitly orientated recurrent education towards a broad range of educational objectives, which included "individual development" and "equality of opportunity" (ibid., p. 33). It thus gave recurrent education the double task of compensating "for the inequalities of the present and near future" (ibid., p. 39) and of "spreading educational opportunity over a longer period of an individual's life" (ibid.).

\section{The Delors report - UNESCO's follow-up to the Faure report}

Two decades later, UNESCO's view on lifelong learning and the learning society still displayed strong traces of the humanistic and political approach of the Faure report. The 1996 report Learning: The treasure within (Delors et al. 1996) - written for UNESCO by the International Commission for Education in the TwentyFirst Century under the chairmanship of Jacques Delors and published during the "European year of lifelong learning"7 - expands on Faure's idea of "learning to be" by adding three further "pillars" of education : "learning to know", "learning to do", and "learning to live together". The report argued for the need "to rethink and broaden the notion of lifelong education" so that it not only focuses on adaptation "to changes in the nature of work" but also constitutes "a continuous process of forming whole human beings" (ibid., p. 19). It also argued for a shift in attention "from social cohesion to democratic participation" (ibid., chapter 2) and "from economic growth to human development" (ibid., chapter 3), and paid explicit attention to the political, democratic and global dimensions of lifelong learning.

\section{Lifelong learning for all - OECD's human capital reasoning in the late 1990s}

Learning: The treasure within (Delors et al. 1996) can be read as a response to a rapidly emerging alternative policy discourse that was strongly characterised by an

\footnotetext{
7 "The aim" of the European Parliament and the Council of the European Union's decision to establish 1996 as the European year of lifelong learning was "the promotion of personal development and sense of initiative of individuals, their integration into working life and society, their participation in the democratic decision-making process and their ability to adjust to economic, technological and social change" (EC 1995, p. L 256/46).
} 
economic rationale and a focus on lifelong learning as the development of human capital. The idea that lifelong learning is first and foremost about the development of human capital so as to secure competitiveness and economic growth played a central role in a document published by the OECD in 1997, with the title Lifelong Learning for All (OECD 1997). Lifelong Learning for All put a very strong emphasis on the economic rationale for lifelong learning - itself understood in the rather formal sense as learning "throughout life" (ibid., p. 15). It presented the idea of "lifelong learning for all" as

the guiding principle for policy strategies that will respond directly to the need to improve the capacity of individuals, families, workplaces and communities to continuously adapt and renew (ibid., p. 13).

Such adaptation and renewal were presented as necessary in the face of changes in the global economy and the world of work, including the

large and continuing shift in employment from manufacturing industry to services, the gathering momentum of globalisation, the wide diffusion of information and communications technologies, and the increasing importance of knowledge and skills in production and services (ibid., p. 13).

\section{The rise of the learning economy}

According to Lifelong Learning for All (OECD 1997), the disappearance of many unskilled jobs, the more rapid turnover of products and services, and the fact that people change jobs more often than previously, all point to the need for "more frequent renewal of knowledge and skills" (ibid., p. 13). Lifelong learning "from early childhood education to active learning in retirement" was thus presented as "an important factor in promoting employment and economic development", and, in addition to this, also in promoting "democracy and social cohesion" (ibid., p. 13). Whereas, as mentioned, the Delors report made a case for shifting the attention from social cohesion to democratic participation and from economic growth to human development, Lifelong Learning for All went in the opposite direction in its consideration of economic growth, and saw democracy and social cohesion as compatible "agendas" rather than as goals which are potentially in tension with each other.

\section{The 1993 White Paper on growth, competitiveness and employment}

The economic imperative is also clearly visible in documents and statements emerging from the European Union (EU) in the 1990s and the first decade of the 21st century. Another document in which Jacques Delors had a hand - the 1993 White Paper Growth, Competitiveness, Employment: The challenges and ways forward into the 21st century (EC 1993) - put "lifelong education and training" first in its list of 
six "priorities for action on jobs" (ibid., p. 16) and made lifelong learning ${ }^{8}$ a central plank in the general objectives of a proposed reform of education and vocational training systems (ibid., pp. 119-121). The 1993 White Paper provided important groundwork for the "Lisbon Strategy" which was launched in 2000 (see Jones 2005) and which not only formulated the strategic goal for the EU "to become the most competitive and dynamic knowledge-based economy in the world, capable of sustainable economic growth with more and better jobs and greater social cohesion" (Council of the European Union 2000; emphasis in original), but also gave lifelong learning a central role in this, first and foremost as the provider of "new basic skills" such as "IT skills, foreign languages, technological culture, entrepreneurship and social skills" (ibid.) explicitly geared towards the creation of "more and better jobs for Europe" (ibid.). More generally, the Strategy's approach was conceived in terms of the "need to adapt both to the demands of the knowledge society and to the need for an improved level and quality of employment", with a particular focus on

learning and training opportunities tailored to target groups at different stages of their lives: young people, unemployed adults and those in employment who are at risk of seeing their skills overtaken by rapid change (ibid.).

While EU decisions about education are firmly rooted at the level of individual member countries, the Union, both through the rhetorical force of its documents and through the "open method of coordination" (see Frederiksson 2003) nonetheless exerts a powerful influence on the policy landscape of lifelong learning. In the first decade of the 21 st century we can see further interventions in the domain of lifelong learning brought about by European policies, particularly in the context of the Education and Training 2010 and the Education and Training 2020 strategies (EC 2004, 2009). In these and related documents, lifelong learning remains positioned as a device for adjustment and adaptation and, more specifically, for the development of human capital. The European Lifelong Learning Indicators Conceptual Framework paper (ELLI Development Team 2008) formulates it as follows (referring to a 2003 document on "What is lifelong learning?" from the European Commission which is no longer retrievable).

In a knowledge society where demands for skills, competencies and knowledge constantly increase and change, lifelong learning is a key strategy to adjust human capital to new requirements, e.g. caused by technological change. More generally, one may consider lifelong learning as a reaction to an acceleration of social, economic and technological change (ELLI Development Team 2008, p. 8).

I am using this quotation because it expresses in an extremely clear way the complete reversal of where the Faure report entered the discussion. To suggest that lifelong learning is a key strategy for adjusting human capital to new requirements is not just remarkable in terms of an apparent lack of interest in where such new

\footnotetext{
${ }^{8}$ It is not without significance that within this document there is a shift from the notion of "lifelong education" to that of "lifelong learning".
} 
requirements come from and whose interests they are serving, simply assuming that the dynamics of global capitalism are a "fact of nature". This suggestion is also noteworthy because it does not seem to be interested at all in who the units of "human capital" actually are and whether they might perhaps be inclined to pursue different avenues and ambitions in their individual and collective lives, perhaps even avenues and ambitions that will serve their complete fulfilment.

\section{Shifting agendas or shifting relationships?}

So far, I have summarised key tenets of the Faure report and have positioned the report in a longer-term trajectory. I have highlighted the shift from regarding lifelong education as a right to promoting lifelong learning as a duty. It is first of all the shift from right to duty that is significant here, particularly because it signifies a radical reversal of responsibilities and a radical change of the relationship between governments and citizens. As long as lifelong education is seen as a right of citizens, there is a duty on governments to make this right real - which is first of all a matter of the provision of educational opportunities and of securing access for all. When lifelong learning becomes a duty, the onus is shifted to individuals and their responsibility in ensuring that they adjust and adapt by upgrading their knowledge and skills. In such a set-up, which can be characterised as neoliberal, governments retreat as providers - they tend to leave the provision to "the market" - but nonetheless play an important role as controller of quality or, more indirectly, as regulator of privatised quality control entities (see e.g. Milana et al. 2020 on Europe's lifelong learning markets).

It is, however, also the terminological - and thus, conceptual - change from "education" to "learning" that is significant here. Again, if "education" highlights a focus on provision - and hence on structures and infrastructure and the question as to what should be on "offer" - "learning" is a much more malleable concept that seems to refer to change, ${ }^{9}$ without an indication of what the change should be about, what it should be for, and who should have a voice in deciding about the answers to these questions. The rise of the language of learning and the "learnification" (Biesta 2010) of educational discourse and practice more generally has brought about a situation which has enabled the idea that learning is about adjustment to changes in the environment to become "common sense". The language of learning has made it possible, in other words, to talk about the alleged inevitability of adapting in an "increasingly rapid" tempo.

It is not just a problem that it is "the environment" that seems to set the course of direction for such learning, which clearly takes agency away from those who need to adjust and adapt and makes rather invisible those who are actually setting the agenda. It is also a problem that in such a set-up the idea that there may actually be

\footnotetext{
9 A widespread entirely formal definition of learning is that it is any more or less durable change which is not the result of maturation (i.e. simply growing older), but rather brought about by interaction with an environment.
} 
good reasons for resisting adaptation and adjustment seems to be absent. Whereas the turn towards learning is often presented as an emancipatory move since it suggests a liberation from top-down control exerted by teachers or educational institutions, the rise of the learning economy can hardly be seen as a liberating movement, since it demands from individuals that they continuously adapt to increasingly abstract forces and circumstances.

At one level we could say that the trajectory from Faure onwards simply reflects a change in priorities and a subsequent change in the agendas for education through the life-course. We could even say that over time a different "hegemony" has established itself, which is not only about how particular actors have become more influential over time, but also how a particular discourse has given some actors more power and influence than others. Hegemony is, after all, about how a particular "common sense" is established, that is, how a particular "sense" becomes common sense, so that some things make sense and other things no longer make sense. Jacques Rancière refers to this dynamic with the helpful notion of "partage du sensible", which in English is both about the distribution of what makes sense and the division between what makes sense and what no longer makes sense (see Rancière 2000; see also Durham and Gaonkar 2019).

The point I wish to make here, however, is that the trajectory from Faure onwards can also be understood as a change in the articulation of the relationship between education and society. What is striking about the more recent discourse on lifelong learning is that it assumes an entirely functional role for education vis-à-vis society. It is, in other words, society that sets the agenda, and it is education - in the guise of lifelong learning - which is expected to deliver this agenda. This discourse thus approaches education as an instrument for "delivering" particular goods and is therefore only interested in the extent to which education is able to deliver these goods. It is, in other words, interested in questions of effectiveness and efficiency but not, we might say, in the "integrity" of education itself. And this also helps to explain why the global education measurement industry is still booming (see Biesta 2015; D’Agnese 2017)

Rather, therefore, than seeing the trajectory "since" Faure as a shift from a humanistic to an economic agenda - which always puts UNESCO on the back foot in wanting to defend its humanist outlook and orientation in the face of economic "realities" - we could also see Faure as articulating a fundamentally different understanding of the relationship between education and society. Or, to put it differently, we could read the Faure report as making a case for education itself, if such an expression makes sense, rather than seeing education as a more or less perfect, more or less effective, and more or less efficient instrument for whatever agenda is prominent or hegemonic at a particular point in time (for extended discussions on this, see also Biesta 2019, in press[a], in press[b]). To grasp the significance of this reading, I turn to an interesting essay written by the German educational thinker Klaus Mollenhauer at about the same time as Faure and his colleagues were working on their report. The essay, entitled "Funktionalität und Disfunktionalität der Erziehung" [Functionality and dysfunctionality of education] appeared in Mollenhauer's book Erziehung und Emanzipation [Education and emancipation] (Mollenhauer 1968). 


\section{Dysfunctionality and the problem of education}

While there is a strong tendency in educational policy and research to explore and ensure how education can be made to function better, that is, more effectively and efficiently in relation to certain agendas and purposes, Mollenhauer enters the discussion from the opposite end of the spectrum by asking how we should understand and appreciate what he refers to as the dysfunctionality of education. By this term, he means the situation where education is precisely not delivering on the agendas set for it and therefore, from the point of view of such agendas, appears as dysfunctional. The question he asks is whether this situation just presents a problem that needs to be solved, or whether it might be the case that the apparent dysfunctionality of education vis-à-vis the context surrounding it actually reveals something important about education itself.

One argument in favour of the "societal dysfunctionality" of education, Mollenhauer contends, is the idea that education can never just be about the insertion of the new generation into the existing social order - education as adaptation - but also has a role to play in helping children and young people to find their own position in society - education as emancipation (see Mollenhauer 1968, pp. 22-23). Regarded from this angle, the role of education is not just to secure the continuation of the past and the present; it also needs to have an orientation towards the future, particularly with the intention of keeping the future "open" for the new generation rather than determining their future for them. In this line of thinking, which is already visible in the work of 18th-century authors such as Jean-Jacques Rousseau, Friedrich Schleiermacher and Nicolas de Condorcet (see Mollenhauer 1968, pp. 26-27), the new generation is not simply seen as a "recruitment pool" for society, as Mollenhauer puts it (ibid., p. 24), just as education is not simply there to "fill" this pool, as it were.

It is important to see, however, that Mollenhauer's analysis of the dysfunctional side of education is not an argument for a romantic view of education in which a choice in favour of the new generation is seen as a choice against society. The danger with such a view, Mollenhauer argues, is that it isolates education from society and thus thinks of emancipation as something entirely focused on individual children and their development, without paying attention to societal dynamics and settings. According to Mollenhauer, such a disconnection of education from society - known in the literature as the creation of an educational "province" - was the main problem with German educational thought and practice in the first decades of the 20th century. It made education vulnerable for ideological misappropriation, which is exactly what happened with education in Germany during the rise of Nazism.

Mollenhauer concludes, therefore, that with regard to the relationship between education and society, the question is not how we can protect education from society, but how we should understand the relationship between the two, if, that is, we do not want to think of this relationship in purely functional terms - education as an instrument for society's agendas - but also do not want to disconnect education from society. In order to address this question, Mollenhauer turns to social theory, arguing that the question of the relationship between school and society is not just a matter for educational theory but also requires societal analysis. 
Mollenhauer's own exploration takes him to a comparison between the structuralfunctionalism of American sociologist Talcott Parsons and the work of Charles Wright Mills. ${ }^{10}$ Central to Parsons' work is the idea that social stability depends on the existence of shared values. Social stability thus requires value consensus, but we might also say that social stability appears as value consensus. On this assumption, education's dysfunctionality vis-à-vis society's consensus can only be seen as a threat to social stability, and thus becomes more or less a problem that needs to be solved by trying to align education more strongly with society's values. One could even say that this assumption makes education appear as the key institution for bringing about society's value consensus. Education, in other words, thus becomes a key institution for the normative socialisation of the new generation (ibid., pp. 28-29).

Whereas for Parsons social plurality poses a threat to the social order, Mills starts from the opposite assumption, by arguing that the existence of value plurality and even of a conflict of values is part of society's normality. Value plurality is, in other words, not a problem that needs to be solved, but rather part and parcel of what (a) society is. According to Mollenhauer, this brings into view that the idea that society is only possible on the basis of a value consensus is an ideological view which is largely at odds with the idea of society as a democratic society (ibid., pp. 30-31). The word "largely" is important here, because a democratic society is neither valuefree, nor is it an "anarchy of values". Rather, a democratic society is bound by a particular set of political values, namely those of liberty, equality and solidarity, except that in a democratic society there is an ongoing question about what such values mean in practice (on this, see Mouffe 2000, 2005). Such values are political because they are there to make a plurality of values - or in the language of political liberalism: a plurality of "conceptions of the good life" - possible.

Against this background Mollenhauer argues that conflict and antagonism, particularly with regard to the question of education's "agenda", should not be seen as dysfunctional "moments" of an otherwise functioning system, but should rather be seen as constitutive of educational practices (Mollenhauer 1968, p. 35) - provided, of course, such practices are interested in democracy. This is why he argues that education in schools and other settings should be understood in terms of the interaction between a "multiplicity of fields" (ibid.), and not in terms of unity and consensus around a singular vision or agenda. This is so for the sake of education - which should never be reduced to mere adjustment of the new generation to an existing societal "order" - and for the sake of democracy - which should never strive for value consensus on the assumption that society would not be possible without it.

The point I wish to emphasise here is that the educational and the democratic dimensions of the argument are both important. And this is even more so with regard

\footnotetext{
10 The work of American sociologist C. Wright Mills does not have a clear label, but what is clear is his interest in pluralism and democracy which shows affinity with pragmatism and Marxism, and positions him closer to the work of Max Weber (see Treviño 2012).
} 
to the question of the relationship between education and society. ${ }^{11}$ After all, if we only engage with this question in terms of democracy, we may end up with a multiplicity of agendas for education, all of which, on their own, might still see education as an instrument for delivering these agendas. To put it differently: the democratic case against a singular agenda for education is not, in itself, a sufficient response to the instrumentalisation of education. It is only when the educational argument is brought in - that is, the idea that education can never be about the insertion of the new generation into particular societal orders - that education's "own" interest, as it were, can be pursued. It is only when this interest is brought into play that it becomes possible for education to resist attempts to turn it into a perfect instrument for the socialisation of the new generation. And it is only when this interest is brought into play that it becomes possible to see where and why education has a "duty to resist", as French educational scholar Philippe Meirieu put it (see Meirieu 2007).

James Donald very helpfully captured these issues under the heading of the "problem of education" (see Donald 1992). On the one hand, the idea of the problem of education refers to the fact that so many of the bigger and smaller ambitions for education tend to fail, that is, they have a propensity for never being able to be realised completely. But rather than seeing this as a problem that needs to be solved, Donald suggests that this particular problem, that is, the ongoing inability of education to become a perfect instrument, is actually the very point of education. It is where education differs from indoctrination and manipulation, and this has everything to do with the fact that education, unlike indoctrination and manipulation, is interested in the freedom and agency of those who take part in it, rather than seeing their freedom and agency as "issues" that need to be eradicated. ${ }^{12}$

Donald makes his case with reference to Sigmund Freud's observation that education is one of the three "impossible professions" (Freud 1937) where one can never be certain about the outcome of one's actions (as educator). For Freud, the other two impossible professions are politics and psychoanalysis, and the reason why they are impossible is not because they lack technical efficacy, but because they have an orientation towards other human beings as subjects of their own life, not as objects of more or less effective interventions. In this regard the field of education might perhaps best be compared to the field of law, not just because both fields operate on the assumption that human beings are free agents who can take responsibility for their own actions - without that assumption both fields would immediately

\footnotetext{
11 With regard to this point I think that Mollenhauer's case for keeping education connected to a plurality of agendas is actually still vulnerable, also in terms of his own ambitions (see Biesta in press[a]).

12 In this article I have mainly emphasised the problem with making education into a perfect instrument for socialisation, that is, for adapting and adjusting the new generation to the existing societal order. The argument, however, also has implications for more progressive ambitions, such as the idea that education should bring about equal opportunities for everyone or, even more ambitiously, equal educational outcomes. Elsewhere (Biesta 2020), I have suggested that while education may be able to "deliver" on such goals, it is unlikely that it will be able to "deliver" on this for everyone. In this regard, the problem is not whether education is driven by conservative or progressive agendas or ambitions, but whether education is reduced to an instrument in pursuing such ambitions.
} 
become meaningless - but also because both fields never give up hope that human beings will take their freedom seriously and will indeed be able to take their freedom seriously.

\section{Conclusion: Faure, the future, and the emancipation of education}

In this article I have provided a reading of the Faure report in light of the evolution of educational discourse, policy and practice during the five decades that separate us from the moment in time when the report was published. I have tried to capture the particular "ethos" of the Faure report, highlighting solidarity, fulfilment and lifelong education as three distinctive themes, and have shown how these themes have been marginalised over the past five decades in favour of what many would characterise as an economic agenda for lifelong learning. And what is significant here, as I have tried to make clear, is not just that the economic interest has pushed out the democratic interest. It is also that a discourse of education has been replaced by a discourse of learning, thus making education first and foremost an individual matter - something for individual lifelong learners to take responsibility for - and also making it increasingly a formal matter - something that is about adjustment and adaptation to whatever environment presents itself.

One way to think about these developments is in terms of shifting agendas for education, that is, where UNESCO's humanistic agenda has been overtaken by an entirely economic agenda, voiced by other agencies such as OECD and the World Bank. The suggestion I have pursued in this article, however, is that rather than thinking about these developments in terms of a shift in agendas, it may also be possible to see it as a shift in the relationship between education and society and, more precisely, the rise of an entirely functionalist approach to education. The problem with the economic agenda may not so much be the agenda itself - the economic argument is, after all, not trivial - but the fact that the rise of this agenda is constantly turning education into an instrument, and thus pushing hard on making this instrument more effective and efficient. Therefore, rather than countering only the rise of what I have termed the "learning economy" with arguments in favour of UNESCO's humanism - which can be done of course and, in itself, is not at all trivial either - I have suggested that there is also a need to counter the ongoing functionalisation of education. Moreover, I think that this is perhaps the more urgent need, because there is a risk that a battle over agendas - be they economic, humanistic, technocratic or democratic - will still end up turning to education as the instrument for delivery.

Another way of putting it is that UNESCO's humanism which, rather than an -ism is perhaps better understood as an ongoing concern for the dignity of all human beings, is not so much something that should come to education from the outside - as an agenda - but can actually be found on the inside of education itself if, that is, we take pride in the problem of education, we take pride in the impossibility of perfecting it, rather than seeing it as a lack that needs repairing. What is required, therefore, in order to reclaim the future of education that was hinted at in the Faure report - a future that has not yet been - is the emancipation of education itself, that 
is, the liberation from ongoing attempts to see and approach education in merely functional and instrumentalist terms. The fact that education, irrespective of where it takes place, has a tendency to resist total perfection may give us some optimism that there is still a future worth fighting for.

Open Access This article is licensed under a Creative Commons Attribution 4.0 International License, which permits use, sharing, adaptation, distribution and reproduction in any medium or format, as long as you give appropriate credit to the original author(s) and the source, provide a link to the Creative Commons licence, and indicate if changes were made. The images or other third party material in this article are included in the article's Creative Commons licence, unless indicated otherwise in a credit line to the material. If material is not included in the article's Creative Commons licence and your intended use is not permitted by statutory regulation or exceeds the permitted use, you will need to obtain permission directly from the copyright holder. To view a copy of this licence, visit http://creativecommons.org/licen ses/by/4.0/.

\section{References}

Biesta, G. (2006). What's the point of lifelong learning if lifelong learning has no point? On the democratic deficit of policies for lifelong learning. European Educational Research Journal, 5(3-4), 169-180. https://doi.org/10.2304/eerj.2006.5.3.169.

Biesta, G. (2010). Good education in an age of measurement: Ethics, politics, democracy. Boulder, CO: Paradigm Publishers.

Biesta, G. (2012). Have lifelong learning and emancipation still something to say to each other? Studies in the Education of Adults, 44(1), 5-20. https://doi.org/10.1080/02660830.2012.11661620.

Biesta, G. (2014). You can't always get what you want: An an-archic view on education, democracy and civic learning. In I. Braendholt Lundegaard \& J. Thorek Jensen (Eds), Museums: Knowledge, democracy, transformation (pp. 110-119). Copenhagen: Danish Agency for Culture.

Biesta, G. (2015). Resisting the seduction of the Global Education Measurement Industry: Notes on the social psychology of PISA. Ethics and education, 10(3), 348-360. https://doi.org/10.1080/17449 642.2015.1106030.

Biesta, G.(2016). Democracy and education revisited: Dewey's democratic deficit. In S. Higgins \& F. Coffield (Eds.), John Dewey's education and democracy: A British tribute (pp. 149-169). London: IoE Press.

Biesta, G. (2019). Obstinate education: Reconnecting school and society. Leiden: Brill I Sense.

Biesta, G. (2020). Perfect education, but not for everyone: On society's need for inequality and the rise of surrogate education. Zeitschrift für Pädagogik, 66(1), 8-14.

Biesta., G. (in press[a]). School-as-institution or school-as-instrument? How to overcome instrumentalism without giving up on democracy. Educational Theory.

Biesta, G. (in press[b]). Does form matter? Defending the good of education beyond agendas. Revista de Educación.

Council of the European Union (2000). Presidency Conclusions on employment, economic reforms and social cohesion: Towards a Europe based on innovation and knowledge [the "Lisbon Strategy"]. Special meeting of the European Council held 23-24 March in Lisbon. Lisbon: Council of the European Union. Retrieved 21 August 2021 from https://www.consilium.europa.eu/uedocs/cms_data/ docs/pressdata/en/ec/00100-r1.en0.htm.

D'Agnese, V. (2017). Reclaiming education in the age of PISA. Challenging OECD's educational order. London/New York: Routledge.

Delors, J., et al. (1996). Learning: The treasure within. Report to UNESCO of the International Commission on Education for the Twenty-first Century. Paris: United Nations Educational, Scientific and Cultural Organization (UNESCO). 
Dewey, J. (1916). Democracy and education: An introduction to the philosophy of education. New York: The Free Press. Retrieved 30 August 2021 from https://archive.org/details/democracyandedu00dew egoog/page/n6/mode/2up?view=theater.

Donald, J. (1992). Sentimental education: Schooling, popular culture, and the regulation of liberty. London/New York: Verso.

Durham, S., \& Gaonkar, D. (Eds) (2019). Distributions of the sensible: Rancière, between aesthetics and politics. Evanston, IL: Northwestern University Press.

EC (European Commission) (1993). Growth, competitiveness, employment: The challenges and ways forward into the 21st century. White Paper. Brussels/Luxembourg: EC. Retrieved 30 August 2021 from https://op.europa.eu/en/publication-detail/-/publication/0d563bc1-f17e-48ab-bb2a-9dd9a31d5004.

EC (1995). Decision No 2493/95/EC of the European Parliament and of the Council of 23 October 1995 establishing 1996 as the "European year of lifelong learning". 95/431/EC. Official Journal of the European Communities. Retrieved 13 September 2021 from https://eur-lex.europa.eu/legal-content/ EN/TXT/PDF/?uri=CELEX:31995D2493\&from=LT.

EC (2004). "Education \& Training 2010". The success of the Lisbon Strategy hinges on urgent reforms. Joint interim report of the Council and the Commission on the implementation of the detailed work programme on the follow-up of the objectives of education and training systems in Europe. 2004/C 104/01. Official Journal of the European Union, 30 April. Retrieved 6 September 2021 from https:// eur-lex.europa.eu/legal-content/EN/TXT/?uri=celex:52004XG0430(01).

EC (2009). Notices from European Union institutions and bodies. Council conclusions of 12 May 2009 on a strategic framework for European cooperation in education and training ("ET 2020"). 2009/C 119/02. Official Journal of the European Union, 28 May. Retrieved 6 September 2021 from https:// eur-lex.europa.eu/legal-content/EN/ALL/?uri=CELEX\%3A52009XG0528\%2801\%29.

Elfert, M. (2018). UNESCO's utopia of lifelong learning. An intellectual history. London/New York: Routledge.

ELLI Development Team (2008). European Lifelong Learning Indicators: Developing a conceptual framework. Gütersloh: Bertelsmann Stiftung.

Faure, E., et al. (1972). Learning to be: The world of education today and tomorrow. Paris/London: UNESCO/Harrap. Retrieved 30 August 2021 from https://unesdoc.unesco.org/ark:/48223/pf0000001801.

Fredriksson, U. (2003). Changes of education policies within the European Union in the light of globalisation. European Educational Research Journal, 2(4), 522-545. https://doi.org/10.2304/eerj.2003.2. 4.3.

Freud, S. (1937). Analysis terminable and interminable. International Journal of Psycho-Analysis, 18, 373-405.

Husén, T. (1974). The learning society. London: Methuen.

Husén, T. (1986). The learning society reconsidered. Oxford: Pergamon Press.

Jessup, G. (1973). L'Education permanente. Studies in Adult Education, 5(1), 16-25. https://doi.org/10. 1080/02660830.1973.11730700.

Jones, H. C. (2005), Lifelong learning in the European Union: Whither the Lisbon Strategy? European Journal of Education, 40(3), 247-260. https://doi.org/10.1111/j.1465-3435.2005.00224.x.

Kallen, D., \& Bengtsson, J. (1973). Recurrent education: A strategy for lifelong learning. Paris: Organisation for Economic Co-operation and Development (OECD)/Centre for Educational Research and Innovation (CERI).

Lindeman, E. (1926). The meaning of adult education. New York: New Republic.

Meirieu, P. (2007). Pédagogie: le devoir de résister [Pedagogy: The duty to resist]. Issy-les-Moulineaux: Éditions Sociales Françaises (ESF).

Messerschmidt, A. (2011). Weiter bilden? Anmerkungen zum lebenslangen Lernen aus erwachsenenbildnerischer und bildungstheoretischer Perspektive [Educate further? Notes on lifelong learning from the perspective of adult education and education theory]. In Kommision Sozialpädagogik der Deutschen Gesellschaft für Erziehungswissenschaft (Ed.), Bildung des Effective Citizen. Sozialpädagogik auf dem Weg zu einem neuen Sozialentwurf [Social pedagogy on the way to a new social design] (pp. 13-24). Weinheim/Munich: Juventa.

Milana, M., Klatt, G., \& Vatrella, S. (Eds.) (2020). Europe's lifelong learning markets, governance and policy. London: Palgrave/Macmillan.

Mollenhauer, K. (1968). Funktionalität und Disfunktionalität der Erziehung [Functionality and dysfunctionality of education]. In K. Mollenhauer, Erziehung und Emanzipation. Polemische Skizzen [Education and emancipation: Polemical sketches] (pp. 32-35). Munich: Juventa Verlag. 
Mouffe, C. (2000). Deliberative democracy and agonistic pluralism. Vienna: Institute for Advanced Studies. Retrieved 30 August 2021 from https://www.ssoar.info/ssoar/handle/document/24654.

Mouffe, C. (2005). On the political. London/New York: Routledge.

OECD (Organisation for Economic Co-operation and Development) (1972). Letter dated 6 March from Edwin M. Martin, OECD, to Daniel [sic] Deléon, UNESCO. ADG/ED/13.1. Paris: UNESCO Archives.

OECD (1997). Lifelong learning for all. Meeting of the Education Committee at Ministerial level, 16-17 January 1996. Paris: OECD. Retrieved 13 September 2021 from https://www.voced.edu.au/content/ ngv\%3A25305.

Rancière, J. (2000). La partage du sensible: Esthétique et politique [The distribution of the sensitive: Aesthetics and politics]. Paris: La Fabrique.

Säfström, C. A. (2019). Paideia and the search for freedom in the educational formation of the public of today. Journal of Philosophy of Education, 53(4), 607-618. https://doi.org/10.1111/1467-9752. 12385.

Treviño, A. J. (2012). The social thought of C. Wright Mills. Thousand Oaks, CA: Pine Forge Press.

UIS (UNESCO Institute for Statistics) (2012). International Standard Classification of Education: ISCED 2011. Montreal: UIS. Retrieved 13 September 2021 from https://unesdoc.unesco.org/ark:/ 48223/pf0000219109.

UNESCO (United Nations Educational, Scientific and Cultural Organization) (1975). Education on the move: Extracts from background papers prepared for the report of the International Commission on the Development of Education. Toronto/Paris: The Ontario Institute for Studies in Education/ UNESCO Press. Retrieved 13 September 2012 from https://unesdoc.unesco.org/ark:/48223/pf000 0013298.

Yeaxlee, B. A. (1929). Lifelong education: A sketch of the range and significance of the adult education movement. London: Cassell.

Publisher's Note Springer Nature remains neutral with regard to jurisdictional claims in published maps and institutional affiliations.

Gert Biesta is Professor of Public Education at the Centre for Public Education and Pedagogy at Maynooth University, Ireland, and Professor in Educational Theory and Pedagogy at the Moray House School of Education and Sport, University of Edinburgh, Scotland, UK. He is co-editor of the British Educational Research Journal and The Asia-Pacific Journal of Teacher Education, and associate editor of Educational Theory. His work focuses on the theory of education and the theory and philosophy of educational and social research. Recent books include The beautiful risk of education (Routledge, 2014); The rediscovery of teaching (Routledge, 2017); Obstinate education: Reconnecting school and society (Brill/ Sense, 2019); Educational research: An unorthodox introduction (Bloomsbury, 2020); and World-centred education: A view for the present (Routledge, 2021). So far, his work has appeared in twenty different languages. 